\title{
Kepuasan pasien dalam perawatan periodontal di klinik periodontik rumah sakit gigi dan mulut universitas Padjadjaran
}

\author{
Puspitasari $^{1 *}$, Agus Susanto $^{1}$, Indra Mustika Setia Pribadi $^{1}$ \\ ${ }^{1}$ Departemen Periodonsia, Fakultas Kedokteran Gigi Universitas Padjadjaran, Indonesia \\ *Korespondensi : puspitasari14011@unpad.ac.id
}

\begin{abstract}
ABSTRAK
Pendahuluan : kepuasan pasien terhadap pelayanan di suatu instansi kesehatan merupakan hal yang penting karena termasuk tujuan diadakannya pelayanan kesehatan. Kepuasan pasien berkaitan dengan harapan dan kenyataan dalam pelayanan yang diberikan. Tujuan penelitian adalah untuk mengetahui tingkat kepuasan pasien dalam perawatan periodontal di Klinik Periodontik Rumah Sakit Gigi dan Mulut Universitas Padjadjaran. Metode : Jenis penelitian deskriptif survei menggunakan kuesioner. Sampel ditentukan dengan menggunakan teknik incidental sampling dengan kriteria pasien yang telah atau sedang dirawat oleh residen di Klinik Periodontik Rumah Sakit Gigi dan Mulut Universitas Padjadjaran dari bulan Desember 2017-Februari 2018. Hasil : kepuasan pasien terhadap kemampuan dokter gigi sebesar 82,09\%, ketersediaan alat dan bahan sebesar $80 \%$, kemudahan untuk mendapatkan pelayanan $83,54 \%$, keadaan ruang tunggu $71,54 \%$, kinerja petugas selain dokter gigi 76,15\%, dan pelayanan secara keseluruhan 78,67\%. Hasil akhir dari perhitungan untuk seluruh indikator adalah 78,66\%. Simpulan : pasien merasa puas terhadap perawatan periodontal di Klinik Periodontik Rumah Sakit Gigi dan Mulut Universitas Padjadjaran.
\end{abstract}

Kata kunci : Kepuasan pasien, perawatan periodontal, Klinik Periodontik

\section{Patient satisfaction level of periodontal treatment in clinic of periodontics Universitas Padjadjaran Dental Hospital}

\section{ABSTRACT}

Introduction: patient satisfaction on services that provided by a health agency is important because it is one of the reasons why health service is being held. Patient satisfaction depends on expectation and the quality of service that is given. This study aimed to know about patient satisfaction level on periodontal treatment in Clinic of Periodontics Rumah Sakit Gigi dan Mulut Universitas Padjadjaran. Methods: this is descriptive study with survei technique used a questionnaire to collect data. Sample was determined by using incidental sampling technique with criteria of a patient who is being treated or have been treated by the resident in Clinic of Periodontics Rumah Sakit Gigi dan Mulut Universitas Padjadjaran by December 2017-February 2018. Results: patient satisfaction about the dentists performance is $82,09 \%$, about dental instrument they had is $80 \%$, about accessibility to dental care is $83,54 \%$, about physical exterior of the waiting room is $71,54 \%$, about the staff other than the dentist is $76,15 \%$ and overall satisfaction is $78,67 \%$. The final result of those indicators is $78,66 \%$. Conclusion: this study shows that patients are satisfied with periodontal treatment in Clinic of Periodontics Rumah Sakit Gigi dan Mulut Universitas Padjadjaran.

Keywords : Patient satisfaction, periodontal treatment, clinic of periodontics 


\section{PENDAHULUAN}

Riset Kesehatan Dasar Tahun 2013 Kementrian Kesehatan Republik Indonesia pada 497 kabupaten/ kota, prevalensi jaringan periodontal sehat sebesar $4,79 \%$ atau 34.614 orang, sedangkan jaringan periodontal tidak sehatsebesar $95,21 \%$ atau 687.715 orang. ${ }^{1}$ Melihat bahwa prevalensi terjadinya penyakit jaringan periodontal di Indonesia cukup tinggi, maka menyebabkan tingginya kebutuhan masyarakat atas perawatan periodontal. Poliklinik Periodontik RSGM Universitas Padjadjaran menyediakan layanan bagi masyarakat dengan keluhan pada jaringan periodontalnya. Pasien dengan keluhan pada jaringan periodontalnya akan merasa puas jika semua keluhan yang ia alami sebelumnya menjadi hilang dan rongga mulutnya terasa bersih dan sehat lagi. Kepuasan pasien ini sangat berkaitan dengan kualitas dari pelayanan yang diberikan.

Kepuasan merupakan konsep mengenai kegiatan yang dilakukan untuk merasa cukup dan terpenuhi, kepuasan pasien dapat dicapai jika pasien merasa semua harapannya tentang suatu tindakan telah terpenuhi dan sesuai dengan yang ia bayangkan. ${ }^{2}$ Seorang manusia akan terus mencari barang atau jasa yang dapat mencapai standar kepuasan yang mereka inginkan, karena ingin merasa puas atau dipuaskan itu sendiri merupakan sifat yang pasti dimiliki oleh manusia. Kepuasan pasien akan berpengaruh terhadap pelayanan dan kinerja klinik atau rumah sakit dan juga terhadap kepatuhan pasien itu sendiri. Pasien yang merasa puas dengan pelayanan yang diberikan maka akan timbul rasa loyalitas dalam diri mereka, contohnya pasien akan patuh dengan semua instruksi yang diberikan dokter dan pasien akan datang pada jadwal kontrol yang telah ditentukan sehingga kesehatan gigi dan mulut pasien tersebut menjadi terjaga.

Pasien yang tidak puas akan mencari dokter atau bahkan rumah sakit lain yang dapat memenuhi standar kepuasannya. Era digital sekarang ini, seseorang dapat menuliskan opini negatif dan keluhan mereka tentang orang lain atau sebuah instansi di dunia maya dan itu akan mempengaruhi citra rumah sakit dan dokter yang terkait.,4 Maka, kepuasan pasien merupakan hal penting yang harus diperhatikan oleh pengelola rumah sakit dan sebaiknya dilakukan survei secara rutin. Penelitian tentang kepuasan ini akan memberikan gambaran tentang persepsi pasien tentang keinginan, kebutuhan dan harapan dari pelayanan kesehatan yang akan mereka terima. Kepuasan pasien merupakan salah satu indikator mengenai mutu pelayanan yang diberikan di rumah sakit, dengan mengetahui kepuasan pasien, pihak rumah sakit pun dapat mengetahui kebutuhan pasien untuk mengambil tindakan selanjutnya. ${ }^{5}$

Penelitian sebelumnya yang dilakukan oleh Citrawati pada 2003 tentang tingkat kepuasan pasien terhadap perawatan skeling di Klinik Periodonsia RSGM Universitas Padjadjaran yang menunjukkan kepuasan pasien sebesar 78,16\%.6 Agar diketahui tingkat kepuasan pasien secara keseluruhan maka dilakukanlah penelitian ini yang bertujuan untuk mengetahui tingkat kepuasan pasien terhadap perawatan periodontal di Klinik Periodontik RSGM Universitas Padjadjaran. Perbedaan penelitian ini dengan penelitian sebelumnya adalah subjek yang dilibatkan adalah pasien yang ditangani oleh residen dan tidak terpaku hanya pada satu jenis perawatan. Tujuan penelitian adalah untuk mengetahui tingkat kepuasan pasien dalam perawatan periodontal di Klinik Periodontik Rumah Sakit Gigi dan Mulut Universitas Padjadjaran.

\section{METODE}

Jenis penelitian deskriptif dengan teknik survei. Populasi penelitian adalah semua pasien yang sedang atau sudah menerima perawatan periodontal oleh residen di Klinik Periodontik RSGM Universitas Padjadjaran. Penelitian ini menggunakan teknik incidental sampling. Penelitian dilakukan dengan memberikan kuesioner kepada responden. Penelitian dilakukan mulai dari bulan Desember 2017 sampai Februari 2018 di Klinik Periodontik RSGM Universitas Padjadjaran. Analisis data dilakukan dengan analisis distribusi frekuensi. Nomor surat persetujuan etik untuk penelitian ini adalah 1174/UN6.C.10/PN/2017.

\section{HASIL}

Hasil penelitian terhadap kepuasan pasien disajikan dalam tabel-tabel berikut ini. 


\begin{tabular}{ccc}
\hline & Frekuensi & \% \\
\hline Jenis Kelamin & 27 & 41,53 \\
Laki-laki & 38 & 58,46 \\
Perempuan & & 21,53 \\
Usia & 14 & 16,92 \\
$20-29$ & 11 & 32,30 \\
$30-39$ & 21 & 29,23 \\
$40-49$ & 19 & \\
$\geq 50$ & & 4,61 \\
Tingkat Pendidikan & 3 & 7,69 \\
SD & 5 & 33,84 \\
SMP & 22 & 13,84 \\
SMA/SMK & 9 & 40 \\
Diploma & & \\
Sarjana & 26 & \\
\hline
\end{tabular}

Pasien yang datang ke Klinik Periodontik yang berjenis kelamin perempuan lebih banyak dibandingkan dengan pasien laki-laki karena dari 65 orang pasien yang menjadi responden penelitian. Hal ini menunjukkan bahwa pasien berjenis kelamin perempuan lebih banyak yang datang ke klinik periodontk dibanding pasien laki laki. Sebanyak 38 orang diantaranya perempuan, hal ini dilihat dari karakteristik usia, pasien yang datang ke Klinik Periodontik didominasi oleh kelompok berusia 40-49 tahun. Pasien di klinik Periodontik yang menjadi responden penelitian didominasi oleh lulusan perguruan tinggi, yaitu sebanyak 26 dari 65 responden.

Tabel 2. Kepuasan Pasien Berdasarkan Indikator Klinis

\begin{tabular}{|c|c|c|c|c|c|}
\hline No & Indikator & Kategori & Frekuensi & $\%$ & Kesimpulan \\
\hline \multirow{5}{*}{1} & \multirow{5}{*}{ Kemampuan dokter gigi } & Tidak puas & 0 & 82,09 & Sangat puas \\
\hline & & Kurang puas & 0 & & \\
\hline & & Cukup puas & 2 & & \\
\hline & & Puas & 34 & & \\
\hline & & Sangat puas & 29 & & \\
\hline \multirow{5}{*}{2} & \multirow{5}{*}{$\begin{array}{l}\text { Ketersediaan alat dan } \\
\text { bahan }\end{array}$} & Tidak puas & 0 & 80 & Puas \\
\hline & & Kurang puas & 0 & & \\
\hline & & Cukup puas & 5 & & \\
\hline & & Puas & 41 & & \\
\hline & & Sangat puas & 19 & & \\
\hline
\end{tabular}

Kuesioner yang digunakan dalam penelitian ini terdiri dari pertanyaan mengenai pelayanan klinis dan non klinis. Pada indikator pelayanan klinis, kepuasan pasien diukur dari kepuasan terhadap kemampuan dokter gigi dan ketersediaan alat dan bahan. Nilai tertinggi pada indikator klinis didapatkan pada indikator mengenai kemampuan dokter gigi. Hasil keseluruhannya dapat dilihat pada tabel 2 . 


\begin{tabular}{|c|c|c|c|c|c|}
\hline No & Indikator & Kategori & Frekuensi & $\%$ & Kesimpulan \\
\hline \multirow{5}{*}{1} & $\begin{array}{c}\text { Kemudahan untuk } \\
\text { mendapatkan pelavanan }\end{array}$ & Tidak puas & 0 & \multirow{5}{*}{83,54} & \multirow{5}{*}{ Sangat Puas } \\
\hline & & Kurang puas & 1 & & \\
\hline & & Cukup puas & 6 & & \\
\hline & & Puas & 19 & & \\
\hline & & Sangat puas & 39 & & \\
\hline \multirow{5}{*}{2} & \multirow{4}{*}{ Keadaan ruang tunggu } & Tidak puas & 0 & \multirow{4}{*}{71,54} & \multirow{4}{*}{ Puas } \\
\hline & & Kurang puas & 3 & & \\
\hline & & Cukup puas & 18 & & \\
\hline & & Puas & 40 & & \\
\hline & \multirow{6}{*}{$\begin{array}{l}\text { Kinerja petugas klinik selain } \\
\text { dokter gigi }\end{array}$} & Sangat puas & 4 & \multirow{6}{*}{76,15} & \multirow{6}{*}{ Puas } \\
\hline \multirow{5}{*}{3} & & Tidak puas & 0 & & \\
\hline & & Kurang puas & 1 & & \\
\hline & & Cukup puas & 12 & & \\
\hline & & Puas & 44 & & \\
\hline & & Sangat puas & 8 & & \\
\hline \multirow{5}{*}{4} & \multirow{5}{*}{$\begin{array}{l}\text { Kepuasan terhadap pelayanan } \\
\text { secara keseluruhan }\end{array}$} & Tidak puas & 0 & \multirow{5}{*}{78,67} & \multirow{5}{*}{ Puas } \\
\hline & & Kurang puas & 0 & & \\
\hline & & Cukup puas & 7 & & \\
\hline & & Puas & 39 & & \\
\hline & & Sangat puas & 19 & & \\
\hline
\end{tabular}

Tabel 3 menunjukkan kepuasan pasien terhadap indikator non klinis yang terdiri dari kepuasan terhadap kemudahan untuk mendapatkan pelayanan, keadaan ruang tunggu, kinerja petugas klinik selain dokter gigi, dan kepuasan terhadap pelayanan secara keseluruhan di Klinik Periodontik. Responden memberikan jawaban yang beragam, pada beberapa indikator, ada responden yang masih merasa kurang puas atau cukup puas, tetapi jumlah pasien yang sudah merasa puas tetap mendominasi. Indikator yang mendapat penilaian paling tinggi adalah indikator mengenai kemudahan mendapatkan pelayanan.

Tabel 4. Nilai Total Kepuasan Pasien di Klinik Periodontik

\begin{tabular}{|c|c|c|c|c|}
\hline No & Indikator Kepuasan Pasien & Nilai (\%) & $\begin{array}{c}\text { Total \% } \\
\text { ( } \underline{\Sigma} \text { nilai indikator) } \\
6\end{array}$ & Kategori \\
\hline 1 & Kemampuan dokter gigi & 82,09 & \multirow{6}{*}{78,66} & \multirow{6}{*}{ Puas } \\
\hline 2 & Ketersediaan alat dan bahan & 80 & & \\
\hline 3 & Kemudahan untuk mendapatkan pelayanan & 83,54 & & \\
\hline 4 & Keadaan ruang tunggu & 71,54 & & \\
\hline 5 & Kinerja petugas klinik selain dokter gigi & 76,15 & & \\
\hline 6 & Kepuasan terhadap pelayanan secara keseluruhan & 78,67 & & \\
\hline
\end{tabular}

Secara keseluruhan, tingkat kepuasan pasien dalam perawatan periodontal di Klinik Periodontik Rumah Sakit Gigi dan Mulut Universitas Padjadjaran dapat dihitung dengan membuat rata-rata dari jumlah nilai kepuasan per indikator yang sudah dipaparkan pada tabel-tabel sebelumnya. Setelah dihitung, didapatkan kesimpulan bahwa tingkat kepuasan pasien adalah 78,66\% yang termasuk kedalam kategori puas seperti yang dicantumkan pada tabel 4 . 


\section{PEMBAHASAN}

Hasil penelitian menunjukkan berdasarkan karakteristik jenis kelamin, pasien yang datang ke Klinik Periodontik didominasi oleh perempuan, yaitu sebanyak 38 responden sedangkan responden lakilaki hanya 27 orang. Perubahan fisiologis dan pola hidup dapat mempengaruhi keadaan periodontal seseorang, pada perempuan terdapat beberapa kali perubahan hormonal pada masa pubertas, kehamilan dan menopaus yang dapat mempengaruhi status jaringan periodontal dan mukosa oral, seperti resesi gingiva, xerostomia, gingival enlargement, edema, inflamasi, serta gingivitis pada masa kehamilan dan mentruasi. ${ }^{7}$ Kecenderungan terjadinya penyakit periodontal pada laki-laki tidak kecil, apalagi pada laki-laki yang mempunyai kebiasaan merokok dan malas menjaga kesehatan gigi dan mulut. Selain itu, laki-laki dianggap tidak terlalu memperhatikan penampilan dibandingkan dengan perempuan. Penampilan seseorang didukung salah satunya oleh kesehatan dan keadaan gigi dan mulutnya. ${ }^{8}$

Karakteristik usia, pasien yang datang ke Klinik Periodontik mayoritas berusia 40-49 tahun. Kelompok usia kedua paling banyak adalah yang berusia $\geq 50$ tahun. Hal ini berkaitan dengan usia akan mempengaruhi keadaan tubuh seseorang. Semakin tua usia seseorang, maka akan terjadi penipisan dan penurunan keratinisasi pada epitel gingiva, jaringan periodontal menjadi semakin kasar dan tebal, penurunan jumlah fibroblast, penurunan kolagen pada tulang alveolar, dan akumulasi plak. ${ }^{7}$ Selain itu, semakin tua usia seseorang, kemungkinan menderita penyakit kronisnya semakin tinggi, contohnya diabetes mellitus, yang berpengaruh terhadap kesehatan periodontal. Semakin tua usia seseorang juga berpengaruh terhadap repon imun yang diberikan, menurunnya respon imun merupakan faktor lokal dari destruksi periodontal. ${ }^{9}$ Jika sudah terjadi penyakit pada periodontalnya, efek yang biasanya timbul adalah kegoyangan gigi. Kegoyangan gigi dapat diatasi dengan splinting, keluhan mengenai kegoyangan gigi dan splinting sering ditemui pada pasien di Klinik Periodontik dan splinting merupakan perawatan yang sering dilakukan di klinik ini selain perawatan skeling.
Karakteristik tingkat pendidikan terakhir, pasien di Klinik Periodontik paling banyak merupakan lulusan perguruan tinggi dan diikuti oleh lulusan SMA/ SMK. Tingkat pendidikan seseorang berpengaruh terhadap pengetahuan dan pemahaman tentang kesehatan tubuhnya. Jika seseorang merasakan keluhan yang dirasa mengganggu produktivitasnya, biasanya mereka akan langsung berobat ke dokter. Semakin tinggi tingkat pendidikan seseorang maka kesadaran mengenai masalah kesehatan yang dialami, bagaimana cara mencegah penyakit dan kesadaran untuk datang ke dokter untuk mengatasi keluhannya pun semakin tinggi. ${ }^{10}$

Responden merasa sangat puas terhadap kemampuan dokter gigi. Total nilai kepuasan responden terhadap kemampuan dan cara dokter menangani pasien adalah $82,09 \%$ yang termasuk ke dalam kategori sangat puas. Indikator ini terdiri dari item yang menanyakan tentang jumlah tenaga kerja yang berkompeten, kedisiplinan dokter gigi, rasa empati yang dimiliki dokter gigi, penjelasan mengenai perawatan oleh dokter gigi dan keefektifan dokter gigi dalam merawat pasien.

Banyaknya jumlah tenaga dokter gigi yang berkompeten untuk menangani keluhan-keluhan dan melakukan perawatan yang diinginkan oleh pasien di Klinik Periodontik sehingga pasien tidak perlu dirujuk ke instansi lain hanya karena jumlah dokter gigi yang ada kurang memadai, bahkan ditemukan pula beberapa pasien yang merupakan pasien rujukan dari puskesmas atau rumah sakit lain yang kekurangan tenaga dokter gigi spesialis periodonsia. Dokter gigi yang kompeten disini tidak hanya dinilai dari bagaimana dokter tersebut memilih jenis perawatan yang tepat untuk pasien, tetapi juga dinilai dari keterampilan komunikasi dengan pasien, pemberian informasi yang perlu diketahui pasien, dan rasa peduli terhadap apa yang dirasakan pasien. ${ }^{11}$

Kedisiplinan seorang dokter gigi sangat diperlukan dalam merawat pasien, contohnya dengan tidak membuat pasien menunggu lama hanya karena dokter gigi terlambat datang ke klinik. Responden menilai dokter gigi di Klinik Periodontik bersifat disiplin sehingga memberikan nilai yang tinggi untuk item ini.

Empati merupakan hal yang penting selain kemampuan dokter gigi dalam mengatasi keluhan pasien. Responden merasa bahwa dokter gigi di Klinik Periodontik memiliki rasa empati yang baik. Empati yang dirasakan pasien contohnya adalah ketika dokter gigi mau mendengarkan seluruh keluhan pasien tanpa menghakimi dan menerima pendapat pasien terhadap perawatan yang akan dilakukan. Empati yang dimaksudkan dalam hubungan dokter 
dan pasien adalah "clinical emphaty" dimana empati yang diberikan tidak boleh terlalu berlebihan tetapi tanpa mengesampingkan perasaan dan emosional pasien. Dokter harus bisa memahami perasaan dan mencoba melihat suatu kasus dari perspektif pasien dan mengombinasikannya dengan komunikasi yang baik..$^{12}$ Penyampaian informasi mengenai penyakit dan perawatan yangakan dilakukan sangatlah penting karena berkaitan dengan etik dan menghargai hak otonomi pasien sebelum dilakukannya perawatan. ${ }^{13}$

Penyampaian informasi ini dapat disebut juga sebagai informed consent. Informed consent tidak hanya berupa persetujuan tertulis, dapat juga berupa persetujuan secara lisan, walau lebih baik dilakukan secara tertulis. Persetujuan ini dapat tercapai jika dokter dapat mengkomunikasikan halhal penting kepada pasien yang selanjutnya akan mengarah kepada percayanya pasien terhadap dokter. ${ }^{14}$ Dokter gigi di Klinik Periodontik selalu memberikan informasi-informasi mengenai penyakit yang diderita pasien dan mengenai perawatan yang akan dilakukan beserta segala keuntungan dan komplikasi yang mungkin saja bisa terjadi, dan dokter gigi memberikan kebebasan untuk pasien dalam menentukan perawatan yang akan dijalani selama tidak menimbulkan efek negatif terhadap pasien tersebut sehingga responden memberikan nilai yang tinggi untuk item tersebut.

Keefektifan dokter gigi saat menangani pasien sangat diperlukan, terutama saat menentukan sekiranya perawatan dan pengobatan apa yang dirasa efektif dilakukan terhadap keluhan yang dialami oleh pasien. ${ }^{15}$ Keefektifan disini juga dapat dilihat saat dokter gigi menangani pasiennya, apakah dokter tersebut banyak melakukan hal yang tidak perlu dan cekatan dalam menangani pasien.

Indikator mengenai ketersediaan alat dan bahan yang digunakan selama perawatan. Responden memberikan nilai yang tinggi untuk ketersediaan alat dan bahan di Klinik Periodontik yang ditunjukkan dengan angka kepuasan 80\% yang termasuk kedalam kategori puas. Alat dan bahan yang digunakan dalam perawatan periodontal sudah sesuai dengan peruntukannya dan sudah tersedia lengkap sehingga responden memberikan nilai yang tinggi. Tersedianya alat dan bahan yang lengkap dapat mengefektifkan waktu perawatan sehingga tidak ada hambatan dalam melakukan perawatan, tetapi selain lengkapnya alat, perlu diperhatikan juga apakah alat tersebut berfungsi dengan baik.

Sterilisasi alat diperlukan untuk mencegah adanya infeksi silang dan infeksi nosocomial. ${ }^{16}$ Beberapa responden pernah melihat dokter gigi mengeluarkan alat-alat langsung dari pouch yang biasa digunakan untuk sterilisasi, sehingga responden percaya bahwa alat-alat yang digunakan di Klinik Periodontik sudah steril dan memberikan nilai yang tinggi untuk item ini.
Responden memberikan jawaban sangat puas untuk kemudahan untuk mendapatkan pelayanan yang ditandai dengan angka 83,54\%. Kemudahan untuk mendapatkan pelayanan yang dimaksudkan disini adalah mudah atau tidaknya pasien dalam membuat janji dan mengatur jadwal untuk pertemuan selanjutnya karena seperti yang telah diketahui, perawatan periodontal tidak dapat dilakukan hanya dalam satu kali kunjungan dan membutuhkan kekonsistenan pasien dalam melakukan perawatannya. Pasien di Klinik Periodontik merasa bahwa dokter gigi yang menangani mereka fleksibel dalam menentukan waktu kunjungan dan tidak memaksakan kehendak secara sepihak. Mudahnya akses untuk mendapatkan pelayanan merupakan faktor yang mendukung kepuasan pasien itu sendiri selain keadaan infrastruktur, lamanya waktu menunggu, penjelasan oleh dokter mengenai hal yang perlu diketahui pasien, efisiensi waktu, komunikasi yang baik, dan terjaganya privasi pasien. ${ }^{17}$

Responden merasa puas terhadap keadaan ruang tunggu sehingga responden memberikan nilai $71,54 \%$ yang termasuk ke dalam kategori puas. Ruang tunggu dianggap memadai dan dapat membuat sebagian besar responden merasa nyaman ketika menunggu giliran sebelum dipanggil ke dalam klinik, walaupun pada kenyataannya ruang tungggu klinik hanya terdiri dari beberapa bangku yang disusun di sebuah lorong. Kenyamanan pasien perlu diperhatikan oleh pengelola klinik karena kenyamanan sangat berkaitan dengan kepuasan pasien terhadap pelayanan yang diberikan dan kenyamanan diperlukan ketika menunggu giliran sebelum diperiksa oleh dokter gigi.

Responden merasa sangat puas dengan kinerja karyawan selain dokter gigi yang menangani mereka, sehingga memberikan nilai $76,15 \%$ yang termasuk kedalam kategori puas. Karyawan selain dokter gigi yang dimaksudkan disini adalah staff yang ada di bagian pendaftaran dan staff di bagian Klinik Periodontik. Staff di bagian pendaftaran dan di klinik bersikap ramah dan tanggap terhadap semua pertanyaan dan keluhan pasien. Kepuasan dalam hal ini dapat terjadi jika adanya komunikasi interpersonal yang baik karena komunikasi interpersonal tidak hanya diperlukan oleh dokter gigi saat menangani pasien, tapi diperlukan juga oleh staff non-medis agar dapat memberikan pelayanan yang memuaskan bagi pasien.

Pada dasarnya, semua petugas di klinik harus menghargai hak pasien, privasi dan tidak membedabedakan pasien. ${ }^{18}$ Kategori kepuasan terhadap pelayanan secara keseluruhan, responden memberikan penilaian sangat puas dengan angka 78, 67\%. Kategori ini mencakup item kebersihan klinik, ketanggapan petugas dan dokter gigi terhadap keluhan yang membutuhkan perawatan segera dan kepuasan dengan pelayanan yang diberikan. 
Kebersihan klinik merupakan hal yang dirasakan dan dilihat responden ketika sedang menunggu di ruang tunggu dan ketika sedang dirawat di dental chair. Ketanggapan petugas dan dokter gigi terhadap perawatan yang membutuhkan perawatan segera mendapatkan nilai tinggi dari responden, hal ini berarti dokter gigi dan petugas cepat dan tepat dalam melakukan suatu tindakan. Selanjutnya di item terakhir ditanyakan kepuasan responden terhadap keseluruhan pelayanan yang diberikan dan responden memberikan nilai yang tinggi.

Tingkat kepuasan responden di Klinik Periodontik tercantum pada tabel 4 yang menyatakan bahwa persentase kepuasan pasien terhadap perawatan periodontal di Klinik Periodontik adalah sebesar $78,66 \%$. Angka ini didapat dari total penjumlahan hasil dari seluruh indikator dan dibagi sesuai dengan jumlah indikator.

\section{SIMPULAN}

Tingkat kepuasan pasien terhadap perawatan periodontal di Klinik Periodontik RSGM Universitas Padjadjaran adalah puas.

\section{DAFTAR PUSTAKA}

1. Notohartojo, I., Sihombing, M. Faktor Risiko pada Penyakit Jaringan Periodontal Gigi di Indonesia (RISKESDAS 2013). Bulletin Penelitian Sistem Kesehatan, 2015 : 18(1), 87-94.

2. Oliver, Richard L. Satisfication : A Behavioral Perspective on the Consumer. London \& New York : Routledge Taylor and Francis Group;2015.

3. Kitapci, O., Akdogan, C., \& Dortyol, İ. T. The Impact of Service Quality Dimensions on Patient Satisfaction, Repurchase Intentions and Word-ofMouth Communication in the Public Healthcare Industry. Procedia - Social and Behavioral Sciences. 2014; 148, 161-169. https://doi. org/10.1016/j.sbspro.2014.07.030

4. Pfeffer, J., Zorbach, T., \& Carley, K. M. Understanding online firestorms: Negative word-of-mouth dynamics in social media networks. Journal of Marketing Communications. 2014;20(1-2), 117-128. https://doi.org/10.108 $\underline{0} 13527266.2013 .797778$

5. Dwiatmoko, S. Pengaruh Kualitas Pelayanan Terhadap Kepuasan Pasien di Rumah Sakit Gigi dan Mulut Universitas Jember. Jakarta: Indonesian Journal of Dentistry. 2007.

6. Citrawati, Ni Putu Ria. Tingkat Kepuasan Pasien Setelah Perawatan Skeling di Klinik
Periodonsia Rumah Sakit Gigi dan Mulut Universitas Padjadjaran Periode April-Mei 2003 [skripsi]. Fakultas Kedokteran Gigi Universitas Padjadjaran Bandung ; 2003.

7. Newman, M. G., Takei, H. H., \& Klokkevold, P. R. Carranza's Clinical Periodontology. Retrieved from https://es.scribd.com/doc/196769658/ Carranza; 2015.

8. Gede, Yohanes I K. K., Pandelaki, Karel \& Mariati, Ni Wayan. Hubungan Pengetahuan Kebersihan Gigi dan Mulut dengan Status Kebersihan Gigi dan Mulut pada Siswa SMA Negeri 9 Manado. Jurnal e-Gigi (eG) 2013 ; 1(2), 84-88.Petersen, Poul E., Ogawa, Hiroshi. The Global Burden of Periodontal Disease: Towards Integration with Chronic Disease Prevention and Control. Periodontology $20002012 ; 60,15-39$.

9. Pradono, J., \& Sulistyowati, N. Hubungan Antara Tingkat Pendidikan, Pengetahuan tentang Kesehatan Lingkungan, Perilaku Hidup Sehat dengan Status Kesehatan. Buletin Penelitian Sistem Kesehatan 172013 ;(1),89-95. Retrieved from: $\quad$ https://media.neliti.com/media/ publications/20885-ID-correlation-betweeneducation-level-knowledge-of-environmentalhealth-healthy-be.pdf

10. Sembel, M., Opod, H., \& Hutagalung, B. S. P. Gambaran Tingkat Kepuasan Pasien Terhadap Perawatan Gigi Dan Mulut Di Puskesmas Bahu. E-GIGI 2014 ; 2(2). Retrieved from http:// ejournal.unsrat.ac.id/index.php/egigi/article/ view/5855/5388

11. Caroe, T. Burnout and empathy in primary care. British Journal of General Practice 2012 ; 62(602), 462. https://doi.org/10.3399/ bjgp12X654515

12. Nishimura, A., Carey, J., Erwin, P. J., Tilburt, J. C., Murad, M. H., \& McCormick, J. B. Improving understanding in the research informed consent process:a systematic review of 54 interventions tested in randomized control trials. BMC Medical Ethics, 2013 ; 14(1), 28. https://doi. org/10.1186/1472-6939-14-28.

13. Banerjee, A., \& Sanyal, D. Dynamics of doctorpatient relationship: A cross-sectional study on concordance, trust, and patient enablement. Journal of Family and Community Medicine, 192012 ; (1), 12-19. http://doi. org/10.4103/2230-8229.94006

14. Faden, R. R., Beauchamp, T. L., Kass, N. E., \& Hamel, M. B. Informed Consent, Comparative Effectiveness, and Learning Health Care. New England Journal of Medicine, 2014 ; 370(8), 776- 
8. https://doi.org/10.1056/NEJMhle1313674

15. Greig, J. D., \& Lee, M. B. A review of nosocomial norovirus outbreaks: Infection control interventions found effective. Epidemiology and Infection, 2014 ; 140(7), 1151-1160. https:// doi.org/10.1017/S0950268811002731

16. Ramadani, N., Zhjeqi, V., Berisha, M., Hoxha, R., Gashi, S., Begolli, I., ... Mucaj. Patients' satisfaction with health services at the National Institute of
Public Health of Kosova. Materia Socio Medica, 2016 ; 28(3), 168. https://doi.org/10.5455/ msm.2016.28.168-172

17. Parsapoor, A., Mohammad, K., Afzali, H. M., Ala'eddini, F., \& Larijani, B. Unsatisfied patient's rights: Asurveyontheviews of patients, nursesand physicians. Journal of Medical Ethics and History of Medicine, 2012 ; 5, 4. Retrieved from: http:// www.pubmedcentral.nih.gov/articlerender. 